УДК 378.016:[37.014:005]:34

DOI 10.31654/2663-4902-2021-PP-1-125-131

\title{
Ковальова В. В.
}

начальник відділу кадрів, старший викладач кафедри

гуманітарних дисциплін ПВНЗ «Київський інститут бізнесу та технологій»

kovaleva vika@ukr.net

orcid.org/0000-0003-2015-1060

\section{ДО ПИТАННЯ ФОРМУВАННЯ ПРАВОВОЇ КУЛЬТУРИ МАЙБУТНІХ МЕНЕДЖЕРІВ З АДМІНІСТРАТИВНОЇ ДІЯЛЬНОСТІ}

У статті розглянуто професійну характеристику майбутніх менеджерів $з$ адміністративної діяльності та розкрито можливості навчальних дисциплін у контексті проблеми формування правової культури майбутніх менеджерів з адміністративної діяльності. Аналіз наукової, нормативної та навчальної літератури дозволяє констатувати, що реалізація правової освіти у ЗВО передбачає створення відповідних умов у процесі вивчення правових дисциплін, які мають забезпечувати розвиток особистості майбутнього фрахівия, передусім правовий, його творчу самореалізацію як свідомого громадянина України, а також сприяє фоормуванню високого рівня правової культури, що дозволить йому ефективно розв'язувати правові ситуації в обраній галузі профресійної діяльності. Значні можливості для фоормування правової культури майбутніх менеджерів з адміністративної діяльності першого (бакалаврського) рівня вищої освіти за спеціальністю 073 «Менеджмент» мають навчальні дисципліни («Економічний аналіз підприємства», «Економічна теорія», «Методи розробки та прийняття управлінських рішень», «Менеджмент. Теорія та історія менеджменту», «Менеджмент якості», «Бухаалтерський та управлінський облік»), у яких пропонується розглянути питання щодо свободи особистості, волі та соціальних регуляторів взаємин у суспільстві, відносини особистості і держави, правове регулювання відносин з громадянами тощо. Проведене дослідження не вичерпує багатогранності теоретичних і практичних пошуків розв'язання проблем. Перспективним вважаємо вивчення стану сформованості правової культури в майбутніх менеджерів з адміністративної діяльності.

Ключові слова: правова культура, майбутні менеджери з адміністративної діяльності, можливості навчальних дисциплін у контексті формування правової культури, профресійна характеристика майбутніх менеджерів з адміністративної діяльності.

Постановка проблеми. Формування правової культури студентської молоді один із пріоритетних напрямів професійної освіти, що знаходить відображення в законодавчих та інших нормативно-правових актах, зокрема Конституції України (2016), законах України: «Про Загальнодержавну підтримку молоді на 2004-2008 роки» (2004), «Про вищу освіту» (2014), концепції підвищення правової культури учасників виборчого процесу і референдумів в Україні (2000), Національній програмі правової освіти населення (2001) тощо.

Проблема формування правової культури майбутніх менеджерів з адміністративної діяльності набуває особливої актуальності, оскільки успіх їхньої професійної діяльності буде залежати від рівня правової культури названого вище контингенту бакалаврів.

Аналіз останніх досліджень i публікацій. Питання фрормування правової культури у студентської молоді розглянуто у працях сучасних учених-педагогів Л. Грищенка [2], В. Димочкіної [5], Є. Підлісного [10], М. Подберезського [11] тощо. 
У педагогічному дискурсі окремі аспекти проблеми професійної підготовки менеджерів знайшли відображення в дослідженнях І. Горностаєвої [4], Н. Іванової [6], В. Любарець [7], М. Пономарьової [12] тощо.

Водночас проблему формування правової культури майбутніх менеджерів 3 адміністративної діяльності недостатньо висвітлено в педагогічних дослідженнях.

Мета статті - розглянути професійну характеристику майбутніх менеджерів 3 адміністративної діяльності та розкрити можливості навчальних дисциплін у контексті проблеми формування правової культури майбутніх менеджерів 3 адміністративної діяльності.

Виклад основного матеріалу. Згідно з Національною програмою правової освіти населення основними завданнями правової освіти у ЗВО всіх профілів $€$ такі:

- підвищення рівня правової освіти населення, зокрема учнівської та студентської молоді, викладачів правових дисциплін і викладачів, які висвітлюють правову тематику;

- створення належних умов для набуття здобувачами вищої освіти знань про свої права, свободи, обов'язки;

- широке інформування студентської молоді про правову політику держави та законодавство;

- забезпечення вільного доступу майбутніх фахівців до джерел правової інформації [9].

Зазначимо, що перелічені завдання правової освіти знайшли відображення у змісті програм підготовки фахівців і реалізуються закладами вищої освіти.

Дослідниця Н. Іванова зазначає, що актуальною проблемою сучасного менеджменту $є$ активізація людських ресурсів для досягнення успіху організації. Нова сучасна модель, яка відображає збільшувану інтеграцію економічних і соціальних процесів, ставить перед менеджером також і соціальні завдання забезпечення зайнятості, гуманізацію умов праці, розширення участі в управлінні $[6$, c. 163-165].

Науковець В. Любарець підкреслює необхідність розвинених таких двох груп якостей менеджерів, як-от:

а) професійно-важливі: організаційно-управлінська ініціатива, почуття гумору та самоіронії, суспільне лідерство, культурно-функціональні якості, цілеспрямованість, педантизм і прагматизм, футуристичне бачення розвитку оптимізму, надійність, пунктуальність, природна інтуїтивність і виконавська дисциплінованість, вольова рішучість, щиросердна гостинність, альтруїзм, етичні чесноти, командний колективізм;

б) соціально-управлінські здібності: психолого-педагогічна спроможність, стресостійкість, самовдосконалення, самореалізація, саморозвиток, організаційно-планувальні, адміністративні, корпоративно-політичні, культурологічні, арт-менеджерські, проєктно-конструктивні, комунікативні, реальної оцінки розвитку ситуацій; особистісні якості.

Дослідниця також зауважує, що сучасні управлінці мають володіти задатками, характерними для конкурентоспроможного мобільного лідера, серед яких оперативність у налагодженні особистісних контактів, наявність потужної харизми й уміння переконувати і впевнювати; створення психологічного клімату; здатність до критики і самокритики; дотримання психологічної дистанції; оцінювання й адаптація до ситуації; цілеспрямованість; здатність тривалого ефективного виконання завдань із високою ефективністю; наполегливо досягати поставленої мети; здатність до прийняття самостійних рішень; дисциплінованість; ініціативність.

В. Любарець доходить висновку, що успішність управлінської діяльності менеджера залежить, по-перше, від достатньої сформованості його ресурсів професійної діяльності (комунікативний; мотиваційно-вольовий; діяльнісний) та особистісних якостей і здібностей, що доповнюють його професійний портрет [7, с. 91-93].

Аналіз завдань та обов'язків менеджерів з повною вищою освітою напряму підготовки «Адміністративний менеджмент» (магістр, спеціаліст) та післядипломною 
освітою за напрямом «Адміністративний менеджмент» [8] дозволяє констатувати, що майбутній фрахівець має володіти і комплексом знань, умінь, здібностей і профресійних якостей, важливих для менеджера з адміністративної діяльності, і певною системою компетенцій, пов'язаних із розв'язанням правових питань. Так, обов'язками менеджера $є$ не тільки керівництво діяльністю адміністративної служби підприємства, установи, організації, але й персональна відповідальність перед керівництвом за виконання покладених на нього обов'язків. Він очолює та організовує роботу щодо забезпечення діяльності підприємства внутрішнім адміністративним координуванням та інформаційними зв'язками; формує інформаційнокомунікативну інфрраструктуру підприємства, установи, організації.

До завдань менеджера з адміністративної діяльності також входять розподіл обов'язків між структурними підрозділами служби чи їі працівниками, спрямовування, координація та контроль їхньої роботи. Менеджер подає пропозиції керівництву щодо структури адміністративної служби, вживає заходів стосовно вдосконалення форм і методів роботи персоналу, організовує, регулює та контролює проведення інформаційно-аналітичної роботи підприємства, установи, організації тощо.

Названий вище фрахівець зобов'язаний: брати участь у формуванні заходів щодо визначення корпоративної стратегії підприємства, установи, організації та в межах наданих йому повноважень контролювати їі виконання; у межах делегованих повноважень контролювати стан організаційно-розпорядчої діяльності на підприємстві в цілому та його структурних підрозділах, а також долучатися до організації комплексу заходів щодо забезпечення захисту персоналу [8].

Менеджер з адміністративної діяльності разом із керівниками структурних підрозділів розробляє посадові інструкції та правила внутрішнього трудового розпорядку, вживає заходів щодо забезпечення відповідних умов праці на робочих місцях, забезпечує укладання і виконання колективного договору та роботу щодо ведення діловодства в організації. Разом із керівниками інших структурних підрозділів цей фрахівець розробляє та організовує роботу стосовно упровадження внутрішніх і зовнішніх стандартів ділових документів. Він повинен орієнтуватись у численних і різноманітних правових питаннях, знати законодавчі та нормативно-правові акти щодо організації контролю за виконанням приписів роботи з персоналом, правила і норми трудового законодавства, захисту персоналу та об'єктів господарювання; правила та норми охорони праці, пожежної безпеки і виробничої санітарії тощо [8].

Розкриємо можливості навчальних дисциплін у контексті проблеми формування правової культури майбутніх менеджерів з адміністративної діяльності.

Так, освітньо-професійна програма «Менеджмент» (ОПП) (Київський інститут бізнесу та технологій, економічний факультет, кафедра економіки та підприємництва) для підготовки здобувачів вищої освіти першого (бакалаврського) рівня за спеціальністю 073 «Менеджмент» містить обсяг 240 кредитів ЄКТС, необхідний для здобуття відповідного ступеня вищої освіти. Першою серед перелічених у цьому документі загальних компетентностей $€$ «здатність реалізувати свої права і обов'язки як члена суспільства, усвідомлювати цінності громадянського (демократичного) суспільства та необхідність його сталого розвитку, верховенства права, прав і свобод людини і громадянина в Україні». 3 метою забезпечення формування названої компетентності програмою передбачено викладання обов'язкової навчальної дисципліни «Право» (120 академічних годин).

Дослідниця В. Димочкіна зазначає, що в контексті культурних цінностей право $€$ знаряддям культури, яке сприяє точності знань і вмінь стосовно професійної діяльності. Так, науковець переконана, що студенти не вивчають правознавство в «чистому вигляді», оскільки правові знання переломлюються крізь призму психологічних і фрізіологічних особливостей вікових періодів, з одного боку, а з іншого - «адаптоване» правове знання трансформується в межах методичної системи освітнього процесу. Саме через систему правової освіти здійснюється взаємодія з правовим знанням, яке сприяє розвитку правового мислення, мовлення, інтуїції, франтазії та відчуття гармонії у процесі правової діяльності і практичного застосування правових 
знань у межах освітнього процесу та поза ним [5]. Відтак, вивчення правознавства у процесі фрахової підготовки майбутніх менеджерів з адміністративної діяльності виступає передумовою розвитку їхньої правової культури.

За переконанням Д. Грубіч, викладання права має бути побудовано в такий спосіб, щоб студенти не лише набули певного обсягу знань, який є вкрай необхідним для засвоєння інших дисциплін, а й систематично демонстрували на доступних прикладах можливість і необхідність застосування методів з метою більш глибокого пізнання закономірностей реальних соціальних і виробничих процесів. Здобувач вищої освіти має побачити, як розширення його правових знань збільшує можливості глибшого та детальнішого проникнення у природу речей майбутньої професії $[3$, c. 19].

Одним із найбільш оптимальних шляхів формування правової свідомості та правової культури молоді є засвоєння основ правових знань під час освітнього процесу.

Науковець М. Пономарьова стверджує, що для сучасного менеджера важливою $є$ якісна фахова підготовка. Протягом навчання у ЗВО студенти вивчають майже 60 навчальних дисциплін. Цей перелік включає низку як нормативних гуманітарних дисциплін, так і фундаментальних економічних дисциплін, що сприяє формуванню необхідних знань, умінь і навичок. Професійно орієнтовані дисципліни, спрямовані на фрахову підготовку бакалаврів і формування в них управлінського способу мислення, - це, насамперед, менеджмент, маркетинг, управління персоналом, операційний менеджмент, інноваційний менеджмент, управління проєктами, конфрліктологія, інвестиційний менеджмент, стратегічний менеджмент, методи й технологія прийняття управлінських рішень тощо [12].

Аналіз дисциплін циклу загальної підготовки фрахівців першого (бакалаврського) рівня вищої освіти за спеціальністю 073 «Менеджмент» («Економічний аналіз підприємства», «Економічна теорія», «Методи розробки та прийняття управлінських рішень», «Менеджмент. Теорія та історія менеджменту», «Менеджмент якості», «Бухгалтерський та управлінський облік») дозволив з'ясувати, що зазначені вище дисципліни за метою і завданням містять елементи правових знань. Так, серед основних завдань вивчення навчальної дисципліни «Бухгалтерський та управлінський облік» заявлено набуття студентами таких компетентностей, як «здатність реалізувати свої права і обов'язки як члена суспільства, усвідомлювати цінності громадянського (демократичного) суспільства та необхідність його сталого розвитку, верховенства права, прав і свобод людини і громадянина в Україні».

Мета викладання навчальної дисципліни «Економічна теорія» передбачає ознайомлення студентів із сутністю економічних законів і принципів господарювання в умовах ринкової економіки, з економічною діяльністю суспільства та ії наслідками; висвітлення фундаментальних питань щодо розвитку економіки в сучасних умовах. Особлива увага під час викладання курсу приділяється проблемі ринку та його механізму, законам ринкової економіки, теорії рівноваги, економічного зростання.

Аналіз силабусів навчальних дисциплін дозволив нам стверджувати, що у змісті переважної їх більшості містяться елементи правових знань. Наприклад, у змісті дисципліни «Економічний аналіз підприємства» передбачено семінар «Система оподаткування підприємств і основні напрями її вдосконалення на сучасному етапі», який включає такі теми: «Використання податків для регулювання діяльності підприємства», «Чинний порядок оподаткування прибутку підприємства», «Податок на додану вартість і його вплив на діяльність підприємств», «Відповідальність за недотримання податкового законодавства», «Оподаткування суб'єктів малого підприємництва».

До змісту дисципліни «Методи розробки та прийняття управлінських рішень» включено лекцію «Взаємозв'язок системи прийняття управлінських рішень і нормативно-правової бази», що передбачає висвітлення таких питань: загальні закони; закони інерційності; закони взаємозв'язку із зовнішнім середовищем. 
На думку А. Гетьмана, Л. Герасіної, О. Данильяна, успішність правової підготовки майбутніх фрахівців, підвищення їхньої правової культури може бути досягнуто завдяки реалізації таких умов: 1) системний характер правової підготовки майбутніх фрахівців, включаючи різноманітні форми правового навчання й виховання студентів; 2) безпосередній зв'язок правової підготовки з поетапним засвоєнням розумових дій у студентів, основу яких становлять опанування правових знань і вмінь на базовому й просунутому рівнях; 3) посилення правовиховного впливу на суб'єктів навчання завдяки включення в освітні програми правових курсів, орієнтованих на вивчення теорії та практики, змін у законодавстві; 4) уведення до стандартів професійної освіти блоку правових знань, орієнтованого на підготовку фрахівця конкретної кваліфрікації $[1$, c. 346-347].

Висновки. Аналіз наукової, нормативної та навчальної літератури дозволяє констатувати, що реалізація правової освіти в закладах вищої освіти передбачає створення відповідних умов у процесі вивчення правових дисциплін, які можуть забезпечувати розвиток особистості майбутнього фахівця, передусім правовий, його творчу самореалізацію як свідомого громадянина України, а також сприяти формуванню високого рівня правової культури, що дозволить йому ефективно розв'язувати правові ситуації в обраній галузі професійної діяльності. Значні можливості для формування правової культури студентів, що навчаються за спеціальністю 073 «Менеджмент» мають навчальні дисципліни, у процесі вивчення яких розглядаються питання свободи особистості, волі та соціальних регуляторів взаємин у суспільстві, відносин особистості і держави, правове регулювання відносин 3 громадянами тощо.

Проведене дослідження не вичерпує багатогранності теоретичних і практичних пошуків розв'язання проблем. Перспективним вважаємо вивчення стану сформованості правової культури в майбутніх менеджерів з адміністративної діяльності.

\section{Література}

1. Гетьман А., Герасіна Л., Данильян О. та ін. Правове виховання в сучасній Україні: монограффія. Харків: Право, 2013. 440 с.

2. Грищенко Л. В. Формування правової культури майбутніх учителів у навчальновиховному середовищі педагогічного коледжу: дис. ... канд. пед. наук. Слов'янськ, 2020. $258 \mathrm{c}$.

3. Грубіч Д. Ю. Інноваційні засади загальноправової підготовки майбутнього вчителя: автореф. дис. ... канд. пед. наук. Харків, 2008. 19 с.

4. Горностаева И. Н. Формирование профессионально важних качеств личности будущих менеджеров: дисс. ... канд. пед. наук. Брянск, 2002. 247 с.

5. Димочкіна В. Правова культура особистості у структурі філософрського та психолого-педагогічного знання. Молодь і ринок. 2012. № 12 (95). С. 140-144.

6. Іванова Н.Г. Формування професійно важливих якостей - важлива умова успішного виховання. Педагогічний дискурс. 2012. Вип. 12. С. 163-165.

7. Любарець В.В. Теорія і практика професійної підготовки в умовах інформаційно-освітнього середовища: автореф. дис. ... д-ра пед. наук. Київ, 2019. 43 с.

8. Менеджер (управитель) 3 адміністративної діяльності. URL: https://jobs.ua/dkhp/articles-3666 (дата звернення 10.05.2021).

9. Національна програма правової освіти населення. Офріційний вісник України. 2001. № 3. С. 37-44.

10. Підлісний Є. В. Формування правової культури майбутніх бакалаврів з економіки у процесі фрахової підготовки: дис. ... канд. пед. наук. Умань, 2019. 336 с.

11. Подберезський М. К. Формування правової культури студентів вищих педагогічних навчальних закладів: дис. ... д-ра пед. наук. Харків, 1997. 418 с.

12. Пономарьова М. С. Проблеми і перспективи навчання та підготовки менеджерів. Бізнес-навігатор. 2014. № 2. С. 203-208. 


\section{References}

1. Hetman, A., Herasina, L. \& Danylian O. (2013). Pravove vykhovannia v suchasnii Ukraini [Legal education in modern Ukraine]. Kharkiv: Pravo [in Ukrainian].

2. Hryshchenko, L. V. (2020). Formuvannia pravovoi kultury maibutnikh uchyteliv u navchalno-vykhovnomu seredovyshchi pedahohichnoho koledzhu [Formation of legal culture of future teachers in the educational environment of the pedagogical college]. Candidate's thesis. Sloviansk [in Ukrainian].

3. Hrubich, D. Yu. (2008). Innovatsiini zasady zahalnopravovoi pidhotovky maibutnoho vchytelia [Innovative principles of general legal training of future teachers]. Extended abstract of candidate's thesis. Kharkiv [in Ukrainian].

4. Gornostaeva, I. N. (2002). Formirovanie professionalno vazhnikh kachestv lichnosti budushhikh menedzherov [Formation of professionally important personality traits of future managers]. Candidate's thesis. Bryansk [in Russian].

5. Dymochkina, V. (2012). Pravova kultura osobystosti u strukturi filosofskoho ta psykholoho-pedahohichnoho znannia [Legal culture of specialness and structure of philosophical and psycho-pedantic knowledge]. Molod i rynok - Youth and the market. 12 (95). 140-144 [in Ukrainian].

6. Ivanova, N. H. (2012). Formuvannia profesiino vazhlyvykh yakostei - vazhlyva umova uspishnoho vykhovannia [Formation of professionally important qualities is an important condition for successful education]. Pedahohichnyi dyskurs - Pedagogical discourse. 12. 163165. [in Ukrainian].

7. Liubarets, V. V. (2019). Teoriia i praktyka profesiinoi pidhotovky $v$ umovakh informatsiino-osvitnoho seredovyshcha [Formation of professionally important qualities is an important condition for successful education]. Extended abstract of Doctor's thesis. Kyiv [in Ukrainian].

8. Menedzher (upravytel) z administratyvnoi diialnosti [Manager (manager) of administrative activities]. Retrieved from https://jobs.ua/dkhp/articles-3666 [in Ukrainian].

9. Natsionalna prohrama pravovoi osvity naselennia (2001). [National program of legal education of the population]. Ofitsiinyi visnyk Ukrainy - Official Gazette of Ukraine. 3. 37-44 [in Ukrainian].

10. Pidlisnyi, Ye. V. (2019). Formation of legal culture of future bachelors in economics in the process of professional training [Formation of legal culture of future bachelors in economics in the process of professional training]. Candidate's thesis. Kyiv [in Ukrainian].

11. Podberezskyi, M. K. (1997). Formuvannia pravovoi kultury studentiv vyshchykh pedahohichnykh navchalnykh zakladiv [Formation of legal culture of students of higher pedagogical educational institutions]. Extended abstract of Doctor's thesis. Kharkiv [in Ukrainian].

12. Ponomarova, M. S. (2014). Problemy i perspektyvy navchannia ta pidhotovky menedzheriv [Problems and prospects of learning and preparation managerial]. Biznesnavihator-Business navigator. 2. 203-208 [in Ukrainian].

\section{Kovaleva V.}

Head of the Personnel Department,

Senior Lecturer of the Department of Humanities,

Kyiv Institute of Business and Technology

kovaleva_vika@ukr.net

orcid.org/0000-0003-2015-1060

\section{THE ISSUE OF FORMATION OF FUTURE MANAGERS' LEGAL CULTURE IN ADMINISTRATIVE ACTIVITIES}

The article deals with the professional characteristics of future managers in administrative activities. It reveals the possibilities of academic disciplines in the context of the problem of formation future managers' legal culture in administrative activities. High school plays a leading role in the preparation of intellectually developed, legally competent, mobile, competent, spiritually rich, a professional specialist designed to create the future of the nation. 
Analysis of scientific, normative and educational literature allows to state that implementation of legal education in institutions of higher education involves creation of appropriate conditions during studying legal disciplines, which should ensure development of future specialists, especially legal development, their creative self-realization as a conscious citizen of Ukraine. Moreover, it promotes high level of legal culture that will allow future specialists to resolve effectively legal situations in the chosen field of professional activity. The significant possibilities for the formation of future managers' legal culture in administrative activity of the first level of higher education (Bachelor's) in the specialty 073 Management have such educational disciplines as "Economic analysis of the enterprise», "Economic theory», "Methods of development and management decisions», "Management. Theory and history of management», "Management of quality», "Accounting and management accounting»), which proposes to consider issues of individual freedom, liberty and social regulators of relations in society, relationship between the individual and the state, legal regulation of relations with citizens, etc. The study does not exhaust the diversity of theoretical and practical solutions. We consider promising to study the structure of the legal culture of future managers in administrative activities and pedagogical conditions for the formation of the studied phenomenon in terms of professional training.

Key words: legal culture, future managers in administrative activity, possibilities of educational disciplines in the context of formation of legal culture, professional characteristic of future managers in administrative activity. 